\title{
52. Controversies Relating to the Kuzi Proboscidean Molars. (Contributions to the Geology of the Zyôban Coalfield, V.)
}

\author{
By Hisaktsu YABE, M.J.A. \\ (Comm. Oct. 12, 1950.)
}

Retrospect: Fragmental Proboscidean molars have once been found from Hanareyama near Kuzi-mati, Taga-gun, Ibaraki Prefecture, on the Pacific coast. A note on this occurrence by Tetsunosuke Katô appeared in the Journal of the Geological Society of Tokyo, Vol. XXI'). Instructed by Prof. S. Watase of Zoology, he referred them provisionally to Mastodon latidens Clift (now, Stegolophodon), and this reference has for a while been generally accepted. In one of his paper, H. Matsumoto") stated "One of Katô's specimens from Hanareyama...... which appears also to be referred to the present species" (latidens) "appears to the writer to correspond well in shape and size to $\mathbf{M}^{\prime}$ of the larger race."”)

Katô showed in a columnar section the succession of strata exposed at Hanareyama. At the base of a quarry-wall is exposed a gray tuff-argyllite, his lower division of the Hanareyama Tertiary deposits, followed upwards by a sandstone formatoin, his upper division, which consists in upward sequence of a gray sandstone $3 \mathrm{~m}$, breccia $0.5 \mathrm{~m}$, white sandstone $3 \mathrm{~m}$, and a gray sandstone $3 \mathrm{~m}$; its top is overlain with distinct unconformity by younger deposits, probably of younger Pleistocene age. The sandstone formation is almost horizontal and its boundary to the tuff-argyllite is quite even, as if being conformable to each other. Nevertheless, Katô concluded on several reasons that the two are really unconformable. The molars are from the lower part of the white sandstone.

S. Tokunaga ${ }^{4)}$ who likewise assigned the Kuzi molars to S. latidens maintained on his own field observation that the fossil elephant

1) T. Katô: On the Proboscidean Fossils from Hanareyama, Kuzi-mati, Ibaraki Prefecture (in Japanese). Jour. Geol. Soc. Tokyo, vol. XXI, 1914, pp. 345-349. 1.pl.

2) H. Matsumoto: On Two New Mastodonts and an Archetypal Stegodont of Japan. Sci. Rep. Tôhoku Imp. Univ., Ser. II (Geol.), Vol. X, No. I, 1926, p. 11.

3). He refers to the larger race of Lydekker and Pilgrim. "Mastodon latidens is really entitled to a subdivision into two, a large and a small species, of which the former is to be regarded as the direct descendant of Mastodon cautleyi", quoted from G.E. Pilgrim : The Correlation of the Siwaliks with Mammal Horizons of Europe. Rec. Geol. Surv. India, Vol. XLIII, pt. 4, 1913, p. 294.

4) S. Tokunaga: Geology of the Jôban Coalfield (in Japanese). Mem. Fac Sci. Eng., Waseda Univ., No. 5, 1927, p. 14. 
horizon lies in the sandy tuff-argyllite, which is Katô's lower division. On the other hand, F. Takai ${ }^{5}$ expressed in 1938 that the Kuzi molars may belong to Stegodon elephantoides (Clift) and not to Stegolophodon latidens, and the fossil horizon may be uppermost Pliocene (Calabrian), not Lower Pliocene (Pontian), in geolegical age.

In short, controversies prevail in three points relating to the Kuzi molars, namely: 1) the generic and specific reference, 2) the true stratigraphic position of the elephant bed, and 3) the geological age.

\section{Generic and Specific Reference}

The Kuzi molars are too fragmental for precise specific comparison with known forms; moreover, these specimens are lost. At present, therefore, the students must solely rely upon the figures and descriptions of them given by Katô in his paper cited above. The specimens dealt with by him are two. One of them is in his estimation $18 \mathrm{~cm}$ long, and $8.5 \mathrm{~cm}$ broad, the breadth reducing posteriorly to $7.5 \mathrm{~cm}$. Probably it had six ridges and the ridges preserved are $3.5 \mathrm{~cm}$ high above the intervening valley-bottom and incline somewhat forwards ${ }^{()}$. Most of the ridge-crests have five mamillae, and the most posterior one $e^{\text {) }}$ doubtully six; a mamilla on an extremity of the second posterior ridge is poorly developed, looking like an accessory protuberance. The medial longitudinal sulcus is only vestigial, its trace running between the third and fourth mamillae counted from the right side; the position of this sulcus is most distinct on the first anterior ridge, which worn down by use, is reduced to two truncated cones.

The second specimen has only its anterior half preserved, and moreover, about one-half of the first anterior ridge-crest is missing; this ridge is reduced to two truncated cones; the second anterior ridge-crest has four mamillae, one of which is smaller than the others, and shows a tendency to be reduced into two cones by use. The third ridge-crest has six mamillae, of which the second and fifth ones are smaller. So far is the translation of Katô's description, originally in Japanese.

There is no mention of cement, and his photographs show widely open valleys between ridges; if there existed any cement, it must be very scanty; the photographs further show that the ridges are narrow and tectiform.

5) F. Takai : Cenozoic Mammalia of Japan (in Japanese). Jour. Geol. Soc. Japan, Vol. XLV, 1938, pp. 75i, 752 .

6) This feature seems to indicate that the tooth is from the lower Jaw.

7) Talon. 
The genotype of Stegolophodon Schlesinger 1917 (=Prostegodon Matsumoto, 1924) is Mastodon latidens Clift from the Lower Irrawaddy beds of Burma ${ }^{8}$, and the other referred species are $S$. cautleyi (Lydekker) from the Perim Island formation of Perim Island, S. sublatidens Schlesinger from the Middle Pliocene (?) of Teschen, Austria, S. stegodontoides (Pilgrim) from the Pinjor formation (Upper Siwalik) of India, S. nathoensis Osborn from the Chinji formation (Lower Siwalik) of India, and S. lydekkeri Osborn from the Pliocene ? of Borneo.

The generic characters in common to the teeth of these species are: 1) lophs as in Mastodon and Zygolophodon, tendency to form from four to six transversely arranged cones and conelets (conelets somewhat irregular) and to consolidate into ridge-crests; 2) molar pattern transitional between the Zygolophodon type and the Stegodon type; 3) anterior ridge-crests with persistent median sulcus; 4) cement entirely or almost lacking. The ridge-crest formula of S. latidens is

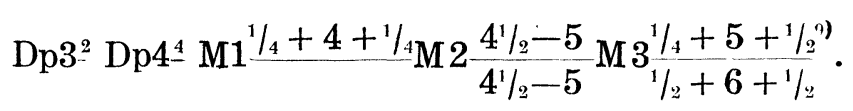

The genotype of Stegodon Falconer and Cautley, 1847, is Stegodon elephantoide (Clift) (=S. clifti Falconer) from the same place and formation as Stegolophodon latidens in Burma, the other well known referred species being Stegodon sinensis Owen from the Lower Pliocene (?) of China, S. bombifrons Falconer and Cautley from the Dhok Pathan (Middle Siwalik) of India, S. insignis-ganesa Falconer and Cautley from the Pinjor and younger horizons of India, S. orientalis Owen from the Lower Pleistocene of China and Lower Pleistocene or/and Upper Pliocene of Japan, S. airawana Martin from the Kendeng beds of Trinil, Java, S. zdanskyi Hopwood from the Middle Pliocene of China, and S. aurorae Matsumoto from the Plioeene (?) of Japan.

The generic characters of Stegodon referred to the dentition are: "Ridge-crests intermediate between Stegolophodon and Archidiscodon planifrons types, progressively multiplying from six to eleven in the intermediate molars, from nine to fifteen and a half in the posterior molars. Cones rapidly subdividing by binary or ternary fissions into multiple conelets. Ridge-crests elevating from brachyodont to subhypsodont. Cement developing in the valleys"'.10)

Compared with Stegolophodon and Stegodon, distinguished from each other as quoted above, the Kuzi molars, though too fragmental, seem to approach more closely the latter genus than the former and may represent a form more primitive than Stegodon elephantoides. The most primitive forms known are S. licenti P. Teilhard de Chardin and M. Trassaert from their Zone I (Lower Pliocene,

8) Now thought by E.H. Colbert to be from the Upper, not Lower, Irrawaddy beds (Lower Pleistocene). H.F. Osborn: Proboscidea, Vol. II, 1942, Chapt. XXII, p. 1450 .

9) * H.F. Osborn, op. cit, p. 830.

10) H.F. Osborn, op. cit., p. 853. 
Pontian) of Shansi, China ${ }^{11)}$, and S. officinalis Hopwood from China (locality and formation unknown). ${ }^{12}$ ) Of the latter species, the author had only two fragmental molars at disposal, which have " the ridge-crests widely spaced with four to five mamillae; first and second ridges of lower molar divided by a median cleft; conules of the upper molars not united into ridges". ${ }^{13}$. While no cement is present in the lower molar, it covers a large part of the talon of the upper molar. The two halves of the anterior ridge are slightly displaced. In all these characters, S. officinalis is more like Stegolophodon than the Kuzi molars, which possess thinner and wide-spaced, more tectiform ridges. Teilhard de Chardin and Trassaert suspected S. officinalis to be specifically indistinct from $S$. zdanskyi which is the most common type of Stegodon in North China, Zone II (Middle Pliocene) and also Zone I (Lower Pliocene) ? ${ }^{14)}$

Stegodon licenti is " a small Stegodon, with remarkably primitive molars; pretrites recognizable and trifoiled on the three or four first ridges; ridges with four or five mamillae (exceptionally eight)".$^{15}$ ) This species is considerably close to such progressive forms of Stegolophodon, as S. lydekkeri from Borneo.

The Kuzi molars are evidently more distant from the typical Stegolophodon than these two species from North China are. All these forms occupy somewhat intermediate position between the typical Stegolophodon and the typical Stegodon, just as Stegodon aurorae from Japan, S. mindanensis Naumann from the Philippines and their allies included by Matsumoto in his Parastegodon are the forms intermediate between the typical Stegodon and the typical Archidiscodon Pohlig.

\section{The Stratigraphical Position of the Mother Rock of the Kuzi Molars}

Sandstones of Katô's upper division of the Hanareyama Tertiary deposits are quarried long since for building material. The Kuzi molars reported by Katô were accidentally unearthed by the quarrymen then working there. Katô, the first geologist to visit Hanareyama since this interesting fossil-find, received from them the information, as he stated, that the molars were obtained from

11) Teilhard de Chardin and M. Trassaert: The Proboscideans of Southeastern Shansi. Pal. Sinica, Ser. C, Vol. XIII, Fasc. 1, 1937, p. 27, Pl. VIII, figs. 1 a, 1 b, 2.

12) A.T. Hopwood: Fossil Proboscidea from China. Pal. Sinica, Ser. C, Vol. IX, Fasc. 3, 1935, p. 73, Pl. VII.

13) A.T. Hopwood, op. cit., p. 73.

14) P. Teilhard de Chardin and M. Trassaert, op. cit., p. 39.

15) Ditto, p. 27.

16) H. Matsumoto: Fossil Elephants of Japan (abridged note, Japanese). Jour. Geol. Soc. Tokyo, Vol. XXXI, pp. 256, 257. 
the white sandstone of the sandstone formation, his upper division. In their visit many years later to this locality, the late R. Aoki and the writer could only confirm, on inquiry to quarrymen, Katô's statement as to the stratigraphical position of the mother rock of the molars. In that occasion, the name Hanareyama sandstone was given by Aoki to the sandstone formation, and the apparent unconformity between the almost horizontal, cross-bedded sandstone and the underlying sandy tuff-argyllite was thought by the writer to be not an erosion unconformity, but to be one produced probably by submarine sliding which has taken place during the continuous sedimentation of the sandy tuff-argyllite. ${ }^{17}$

Later, Tokunaga ${ }^{18}$, dissenting from Katô, declared that the sandstone, fossil elephant bed, belongs in position to the sandy tuffargyllite, saying "The molars are said to have been found in the coarse-grained sandstone with ripple-marks overlying the sandy tuff-argyllite exposed at the quarry-wall. Now looking on the actual exposure of the quarry-wall in comparison with the columnar section of Katô, I contended in finding the fossil elephant bed occupying its position in the sandy tuff-argyllite. Further, the relation of the tuff-argyllite and the uppermost shell bed seems to be unconformable."

The above mentioned observation by Tokunaga and that by Katô on the stratigraphical position of the fossil elephant bed are in contradiction, and liable to lead the most readers to a misconception. It is very regretable that Tokunaga did not fully appreciate what the difference between their observations really means. The readers are here requested to bear in mind that the quarry-wall is temporal, daily regressing by quarrying, and the difference in their observations is not in the interpretation of what they actually observed. The quarry-wall was certainly much receded at the time of Tokunaga than the time of Katô.

At Katô's time, the fossil elephant bed occupied a level a few meters above the boundary plane between the sandy tuff-argyllite and the sandstone formation, while at Tokunaga's time, it was situated at a few meters below the boundary plane; the boundary plane is transfered vertically several meters from one section to the other, relative to the fossil elephant bed. The boundary is, therefore, only superficial and does not represent a stratigraphical boundary in ordinary sense, nor an unconformity as an index of a time gap for erosion. The sandstone formation and the tuffargyllite are contemporaneous.

17) H. Yabe: Recent Stratigraphical and Palaeontological Studies of the Japanese Tertiary. Proc. I Pan-Pac. Sci. Conf., Pt. III, 1921, p. 784.

18) S. Tokunaga, op. cit., p. 14. 
The sandy tuff-argyllite of Hanareyama belongs to the Taga tuff-argyllite, and its relation to the Hanareyama sandstone is quite similar, as already noticed by Tokunaga, to that of the Taga tuffargyllite and Tempizan sandstone exposed at the sea-cliff of Turusizaki near Hidati. ${ }^{\text {19) }}$

The Hanareyama sandstone is an example of the Tempizan sandstone.

\section{The Geological Age of the Kuzi Molars}

As stated above, the Kuzi molars are, according to Watase and Matsumoto, close to those of Stegolophodon latidens, and according to Takai, close to Stegodon elephantoides. Katô and Matsumoto took Stegolophodon latidens as a Lower Pliocene, Pontian, species and Takai considered Stegodon elephantoides as a latest Pliocene, Calabrian, species; on these palaeontological bases, the former two authors assigned the fossil elephant bed of Hanareyama to the Lower Pliocene and the latter to the uppermost Pliocene.

In reality, however, the type specimen of Stegolophodon latidens and that of Stegodon elephantoides are said to have been derived from the lowest level of the Irrawaddy series of Yenangyuang, 25 miles south of Ava, in Burma, usually thought to be correlative with the basal part of the Middle Siwalik of India; the two species are found there in association and therefore regarded as contemporaries.

Lately E. H. Colbert made important remarks regarding the geological age of these fossil elephants, as quoted below :

"Pilgrim, 1910, listed the mastodont, Stegolophodon latidens, as belonging to the Lower Irrawaddy fauna, but this occurrence was questioned by Stamp, in 1922. Subsequent workers in Burma would seem to indicate that this animal is the member of the Upper Siwalik fauna. Certainly a number of discoveries made in recent years establish it as definitely belonging in the Lower Pleistocene of Burma. Therefore, since its presence in the Lower Irrawaddy beds is very doubtfull, it will be considered here as limited to the Pleistocene in Burma"..0)

"The Upper Irrawaddy fauna is in all respects an eastern extension of the typical Upper Siwalik fauna of India. In numerous cases, there is a specific identity between elements constituting the Burmese fauna and these elements in the Pinjor fauna of northwestern India. Where species are not identical in the two

19) H. Yabe: The Taga Beds of the Zyôban Coalfield. This Proceedings, Vol. XXV, 1949, No. 8, pp. 9-17.

20) E.H. Colbert in H.F. Osborn: Proboscidea, Vol. II, 1942, p. 1450. 
regions, they are so closely related as to leave little doubt as to their derivation from common ancestral types. Therefore, there is no reason to regard the Upper Irrawaddy fauna as other than of Lower Pleistocene age, strictly correlative with the Pinjor fauna to the west." "11)

"Stegolophodon latidens from Burma .... would seem to be restricted to the Upper Irrawaddy beds of the Pleistocene age, while in India the species ranges down into the Pliocene Dhok Pathan horizon."

The Dhok Pathan formation, the upper division of the Middle Siwalik, is either Pontian or post-Pontian according to Colber $t^{\text {2:) }}$ and definitely assigned by G. S. Pilgrim to the Pontian; the Pinjor formation, the middle division of the Upper Siwalik, is correlated by the former author to the Lower Pleistocene, and by the latter to the Villafranchian, which he places in the Lower Pleistocene and others in the Uppermost Pliocene.

The age-determination of Cenozoic deposits by means of fossil mammals is generally thought to be most reliable ; frequently their correlation-value is even over-estimated. In the present case, the age-determination of the Hanareyama sandstone on its single Proboscidean species, a rather primitive Stegodon, seems to be an almost hopeless task, seeing on one side, the association of Stegolophodon latidens, and Stegodon elephantoides, in a definite horizon of the Irrawaddy beds, be it upper or lower division, and on the other, the wide geological range of the former species from the Lower Pliocene to the Upper Pliocene, resp. Lower Pleistocene, as stated above.

21) Ditto, p. 1450 .

22) Ditto, p. 1451.

23) E.H. Colbert, loc. cit. 